\title{
Tecnociência, democracia e os desafios éticos das biotecnologias no Brasil
}

\section{CRISTIANE AMARO DA SILVEIRA* JALCIONE ALMEIDA**}

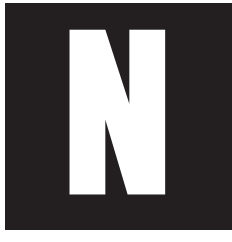

as últimas décadas, a visibilidade alcançada pelas controvérsias e debates em torno das técnicas de engenharia genética tem provocado, ao menos, um certo desconforto naqueles agentes sociais que costumam defender a tecnociência ${ }^{1}$ enquanto signo positivo que, em sua imanência ao progresso da humanidade, garantiria, per se, soluções à diversidade dos problemas enfrentados pelos coletivos sociais modernos. A retórica da tecnociência enquanto "elixir" para resolver os problemas da fome, da desnutrição, da doença e da degradação ambiental já não transita incólu-

\footnotetext{
* Mestre em Desenvolvimento Rural (UFRGS), doutoranda do Programa de Pós-Graduação em Sociologia (PPGS/UFRGS) e Professora-substituta do Departamento de Sociologia da mesma universidade. E-mail: crisasilveira@yahoo.com.br.

** Professor e pesquisador dos programas de pós-graduação em Desenvolvimento Rural e Sociologia, ambos da Universidade Federal do Rio Grande do Sul (UFRGS). Pesquisador CNPq. E-mail: jal@ufrgs.br. Os autores pertencem ao grupo de pesquisa Tecnologia, Meio Ambiente e Sociedade (TEMAS - UFRGS).

1 Tecnociência é um sistema no qual o conhecimento científico e tecnológico encontra-se fortemente associado, atuando mundialmente através de constante inovação na produção e disseminação de artefatos tecnológicos em novos mercados e do suporte financeiro intensivo. Segundo Latour (1994), não se pode pensar a ciência e a tecnologia separadamente.
} 
me sobre a superfície linear ilimitada de uma ciência fundada no lluminismo, esbarrando em uma nova epistemologia do conhecimento, a qual, no sentido popperiano, é construída sobre areia movediça e funda-se, também, em um não-saber (Silveira, 2005).

Resultado tanto dos desenvolvimentos recentes do conhecimento tecnocientífico, como do crescente impacto negativo da atividade humana pelo recurso ao artifício técnico, o atual questionamento das certezas do paradigma iluminista tenciona a uma renovação institucional da modernidade: de um lado, os cientistas vêem-se solicitados a opinar como peritos ${ }^{2}$ a partir de um estado de incerteza no qual o autoritarismo do verdadeiro não mais se sustenta, e o "segredo do príncipe", inscrito nos processos modernos de reconhecimento da autoridade científica e tecnológica é abalado pela inscrição da noção de risco no jogo democrático; de outro, os Estados nacionais sentem-se crescentemente incitados a articular as suas decisões internas a normas e protocolos legitimados internacionalmente e, apoiando-se na objetividade da razão, procuram redefinir os valores sociais, de modo a romper com a separação entre natureza e cultura, entre tecnociência e democracia.

A ciência aliada a uma ética da prudência, eis a pedra-de-toque desta renovação institucional que, para o caso específico da aplicação das técnicas de engenharia genética, seria refletida em políticas nacionais de biossegurança, as quais, integrando a linguagem comum da tecnociência ao valor comum da biodiversidade (biológica e sociocultural), propiciariam um novo contrato social baseado em uma ética ecocentrada. Ética que, contrária ao elogio da inação, ensaia algum tipo de orquestração dos interesses situados entre os ideais da objetividade tecnocientífica e da subjetividade sociopolítica. Mas, afinal, o atual encaminhamento das políticas de

2 Tomado de empréstimo de Giddens (p.35, 1991), o conceito aqui utilizado refere-se "a sistemas de excelência técnica ou competência profissional que organizam grandes áreas dos ambientes material e social em que vivemos hoje". 
biossegurança, especialmente em termos brasileiros, estaria precipitando esta ruptura da separação entre coletivos sociais e natureza, entre tecnociência e democracia? Estariam os cenários de gestão das biotecnologias modernas, ou melhor, das agrobiotecnologias no Brasil, sinalizando para uma renovação institucional nestes termos? Esses são alguns dos questionamentos que o presente artigo se propõe a avançar, ainda que não se pretenda conclusivo.

\section{A contraparte da modernidade: a tecnonatureza e o seu lado sombrio}

A ruptura praticada pelo pensamento moderno entre coletivos sociais (cultura) e natureza, entre tecnociência e democracia, é sintomática da frase de Pascal, o qual, sentindo-se lançado para fora da natureza, afirma: "o silêncio eterno desses espaços infindos aterra-me". Neste sentido, constata-se que a aliança estabelecida entre a modernidade e o Cristianismo foi enfática na sua narrativa da criação: concebe o homem à imagem e semeIhança de Deus, separando-o da natureza e fazendo com que o mesmo dela possa dispor com livre-arbítrio, segundo as suas necessidades.

Por mais que tal narrativa se tenha utilizado da representação platônica do demiurgo enquanto um deus que, não sendo todo-poderoso, não tem o poder de criar o mundo do nada e se tenha limitado a modelar a matéria, ordenando-a a partir do caos preexistente, o pensamento cristão, na verdade, acaba invertendo Platão: se o demiurgo, ao buscar seu nome ao artesão (demiourgos), não fez o que quis, mas obteve os melhores resultados possíveis; o Deus cristão é todo-poderoso, cria o mundo como bem entende, do nada, e não, do caos à ordem. Assim, como o humano cristão é feito à imagem desse Deus, tem a possibilidade de ocupar o seu lugar. Reconhecendo-se um ser antinatureza porque situado fora dela, esse hu- 
mano vê a dominação como única maneira de a ela reintegrar-se (à natureza), de não mais ser aterrorizado pelo silêncio que lhe é infligido dos céus.

Mas, se foi preciso esperar dezessete séculos para que este princípio ético da modernidade, surgido com o Cristianismo, encontrasse finalmente a concepção de natureza que lhe convinha - a de uma natureza despojada de todo mistério e de todo encantamento, a de uma natureza criada, artificializada, da qual se pode dispor e que é possível manipular -, o ideal de aplicação da Física clássica a um mundo que então reclama a sua unificação pela lei da atração universal - o mundo da síntese newtoniana - não resistirá à incansável reprodução dos casos excedentes. O universo e, principalmente, os seres vivos mostraram-se por demais desobedientes para caberem dentro das regularidades de leis universais, e a cada descoberta zoobotânica, os sistemáticos impressionaram-se com a presença de Deus no pormenor, na diversidade (Larrère e Larrère, 1997).

Entretanto, por maiores que tenham sido as dificuldades de generalização de um tal modelo que, ao privilegiar a comunidade científica, bem como as práticas da experimentação e do estabelecimento judicial da prova, mais se assemelhou às monarquias do que à democracia deliberativa da pólis grega, o mesmo acabou configurando-se como um paradigma, à maneira kuhniana, servindo de exemplo às positividades que passaram a se constituir ulteriormente.

Segundo Giddens (1991), é a influência de um tal modo de conceber a modernidade que fez e faz com que os cientistas sociais não a compreendam adequadamente. Para esse autor, portanto, seriam equívocas as orientações culturais e epistemológicas das posições sociológicas atuais, as quais, ao lerem o atual momento a partir de um estado de coisas precedente ou de finalizações, vão defender, respectivamente, ora a emergência de um novo sistema social ("sociedade de consumo", "sociedade de informação" etc.), ora encerramentos ("pós-modernidade", "pós-modernismo", "socie- 
dade pós-industrial"), preterindo, assim, o estudo do fato em si, qual seja, a radicalização da modernidade e as suas conseqüências. E, no que tange particularmente às abordagens epistemológicas recorrentes, Giddens destaca Lyotard, não apenas como vulgarizador da noção de pós-modernidade, mas, principalmente, como precipitador do deslocamento das tentativas de fundamentar a epistemologia e a fé no progresso planejado humanamente, argumentando, todavia, contra ele, o fato de que, ao legitimar heterogêneas reivindicações de conhecimento sem nenhum privilégio à ciência, o mesmo torna impossível a pretensão de um conhecimento sistemático do atual período. Pois, se válida fosse, uma tal proposta repercutiria na própria prática dos cientistas sociais, caso essa ainda se fizesse necessária, uma vez que qualquer esforço no sentido de uma apreensão do atual período seria inútil e, logo, deixado de lado em prol de exercício físico saudável.

Mas, se o esforço de compreensão da modernidade pelos sociólogos também se encontra prejudicado e contaminado por tais interpretações da realidade contemporânea, Giddens condena ainda mais o prejuízo sofrido pelas Ciências Sociais, devido à influência originária das idéias evolucionistas, estas entendidas enquanto "história [que] pode ser contada em termos de um 'enredo' que impõe uma imagem ordenada sobre uma mixórdia de acontecimentos humanos" (p.15, 1991); visto que, ao iluminarem apenas o lado oportunidade da modernidade, deixaram na penumbra o lado sombrio da mesma. E, nesse sentido, esse autor vai afirmar que, se

o desenvolvimento das instituições sociais modernas e sua difusão em escala mundial criaram oportunidades bem maiores para os seres humanos gozarem de uma existência segura e gratificante que qualquer tipo de sistema pré-moderno, a mesma tem também um lado sombrio que se tornou muito aparente no século atual [XX] (p.16, 1991). 
Todavia, a verdade é que, mesmo produzindo os seus trabalhos em um período turbulento, os clássicos, especialmente Marx e Durkheim, valorizaram sobejamente o lado oportunidade da modernidade, pressagiando o surgimento da harmonia e do controle social. Marx fez isso enfocando os desencadeamentos da luta de classes, Durkheim apostando na solidariedade orgânica, fruto da divisão do trabalho e da integração social com preservação da autonomia dos indivíduos. Mesmo Weber, o mais cético dentre os três, embora tenha previsto que o crescente uso da racionalidade e da burocratização tenderia a sufocar a criatividade e a individualidade humana, esteve longe de antecipar o lado sombrio da modernidade. Deste modo, embora os três autores tenham visto o trabalho industrial moderno como possuindo conseqüências degradantes, pois que, submetendo os seres humanos à disciplina de labor maçante, repetitivo, não chegaram a prever que o desenvolvimento das "forças de produção" teria um potencial destrutivo de larga escala em relação ao meio natural.

É de dentro deste contexto que Giddens irá propor uma análise distinta da modernidade, a qual permitiria uma superação da atual dificuldade dos sociólogos em avaliarem as preocupações ambientais (em sua dimensão sombria e estranha à modernidade, tal como concebida pelo lluminismo), partindo do pressuposto que

o mundo em que vivemos hoje é um mundo carregado e perigoso. (...) [E] isso tem servido para fazer mais do que simplesmente enfraquecer ou nos forçar a provar a suposição de que a emergência da modernidade levaria à formação de uma ordem social mais feliz e segura. A perda da crença no 'progresso', é claro, é um dos fatores que fundamentam a dissolução de 'narrativas' da história. Há aqui entretanto, muito mais em jogo do que a conclusão de que a história 'vai a lugar nenhum'. Temos que desenvolver uma análise institucional do caráter de dois gumes da modernidade (p.19, 1991). 
Para o autor, portanto, a desvinculação operada por Nietzsche entre modernidade e pós-modernidade só tratou de desvelar os pressupostos ocultos do lluminismo, sem, para tanto, fazer-nos sair da modernidade. E é neste sentido que Giddens diz ser melhor falar da "modernidade vindo a entender-se a si mesma", visto que, finalmente, o dogma do progresso providencial que deslocou a providência divina libera a razão das certezas iluministas. Deste modo, de agora em diante, nenhum conhecimento pode mais edificar-se sobre fundamentos inquestionáveis, uma vez que, mesmo as noções mais firmemente apoiadas só podem ser vistas como válidas "em princípio" ou "até ulterior consideração".

Em outros termos, tem-se que os fundamentos epistemológicos que sustentaram a pretensão de controle, que permitiram aos humanos, em sua exterioridade, apropriarem-se da natureza para dominá-la, subjugá-la e reinventá-la segundo os seus desígnios, caem por terra ${ }^{3}$. Implode a tese do fim da natureza que fora posta a serviço tanto do elogio à artificialidade, como do elogio fúnebre da natureza, e que se apoiava em uma convicção comum a advogados e acusadores, de que a modernidade teria destruído a natureza. Porém, é justamente dessa implosão que surge a inflexão do paradigma moderno, pois, à artificialização da natureza corresponde, em proporcional medida, a naturalização dos artifícios que então fogem ao nosso controle. Já não há, portanto, tecnosfera, mas uma tecnonatureza que engloba as nossas obras ${ }^{4}$.

3 Em Bruno Latour $(1994 ; 2004)$ também se pode encontrar a idéia de quebra epistemológica e ontológica da relação sociedade (coletivos sociais) - natureza, através da reconfiguração da compreensão histórica e ontológica da forma com que as sociedades construíram suas Constituições a partir da presença de inúmeros não-humanos em aliança com humanos e dos híbridos de cultura e natureza, cuja resultante é o coletivo que vivemos. A noção latouriana de coletivos leva em consideração a participação, em um mesmo espaço, de humanos e não-humanos, simetricamente colocados.

4 Os termos tecnosfera e tecnonatureza são aqui empregados para designar, ora o ideal de uma natureza completamente controlada e manipulada pelo homem, no primeiro caso, ora uma natureza que reage à ação humana de um modo não conforme aos nossos desígnios, produzindo o imprevisível, no segundo caso. 
Obras que construímos com os processos naturais, mas que nos abandonam; obras cujo futuro natural escapa à nossa guarda. Pode-se afirmar, neste sentido, que a natureza continua a existir, e o problema não é a sua falta, mas o fato de termos feito como se ela não existisse, de termos feito como se só existissem máquinas e como se fôssemos exteriores a esse universo.

\section{Uma leitura institucional:}

sistemas peritos e deliberação entre iguais

Assim, como se pretende argumentar, foram os avanços do conhecimento ocorridos ulteriormente à revolução iluminista, os quais acabaram revelando uma natureza que transcende e engloba os humanos, uma natureza que deles prescinde para continuar a sua história. E desta assertiva decorre uma limitação à própria continuidade do modelo ético da modernidade: antropocentrado, o mesmo situava os humanos exteriormente à natureza, em posição de experimentação e controle. Mas estas descobertas, de outro modo, também impedem o retorno ao modelo ético da Antigüidade, o qual, ao situar os humanos, microcosmo no macrocosmo, coloca-o no centro da natureza, em posição de observação. Ora, o atual estado do conhecimento tem implicações não apenas no sentido de contribuir para uma ruptura com esses posicionamentos que privilegiam os humanos em sua relação com a natureza (visto que o antropocentrismo caiu, literalmente, por terra, com o falseamento da teoria geocêntrica), mas também de garantir que os atuais empreendimentos em busca de uma ética sejam orientados por uma visão cientificamente informada. Ecocentrada, uma tal ética nos consideraria exclusivamente companheiros de viagem das outras espécies na odisséia da evolução. Os humanos reinscritos na natureza já não mais desfrutariam de uma posição privilegiada. 
No entanto, as evidências não nos permitem esquecer que a construção de uma visão cientificamente informada da natureza, que rompa com a já consagrada separação entre coletivos sociais e natureza, entre tecnociência e política, não será feita sem a resistência do próprio habitus científico ${ }^{5}$, uma vez que

não é necessário adotar a socioepistemologia de Kuhn para descobrir que as aberturas mais significativas da ciência são justamente, e normalmente, controversas. Ser o porta-voz da natureza, como perito ou no quadro de um debate público, pode reduzir-se a só evocar os conhecimentos consensualmente admitidos. É só levar ao conhecimento dos cidadãos e dos decisores as certezas comuns. Semelhantes convicções correm o sério risco de corresponderem a um estado ultrapassado do saber, o que, em matéria de antecipação, seria contraproducente (Larrère e Larrère, p.257, 1997).

O reconhecimento da incerteza (e da controvérsia) científica e a subseqüente construção social do lado sombrio da modernidade, isto é, a tomada de consciência dos riscos decorrentes da ação humana inscrita na natureza, acabam desencadeando uma rejeição do modelo platônico da autoridade do verdadeiro, do bem ou do belo sobre a comunidade humana e impõem que a natureza e a tecnociência sejam levadas ao interior dos coletivos sociais, que se tornem objeto de um debate público. E se, por esse caminho, terminamos por nos afastar do mundo perfeito e equacionado proposto por Platão, esse mundo do qual poderíamos apropriar-nos pela aplicação objetiva do conhecimento científico e da Matemática, o fato é que tendemos a migrar para o modelo da prudência e do bom uso aristotélico;

5 No sentido bourdiniano, a noção de habitus indica "esse princípio gerador e unificador que retraduz as características intrínsecas e relacionais de uma posição em um estilo de vida unívoco, isto é, em um conjunto unívoco de escolhas de pessoas, de bens, de práticas" (Bourdieu, p.21-22, 1996). 
afinal, "num universo incerto, ou quando se está confrontado com cenários divergentes e indecisos, não é razoável limitar-se a ser racional. Uma ética da prudência é então suscetível de evitar as decisões cujos efeitos podem ter conseqüências nocivas "(Larrère e Larrère, p.194, 1997).

Em outras palavras, a crise ambiental entendida enquanto contexto englobante nas últimas décadas, dos escândalos da doença da vaca louca e de contaminação de frangos por dioxina, dos problemas envolvendo resíduos de agrotóxicos e os riscos de descontrole da energia nuclear, enfim, da própria "questão biotecnológica", convoca os porta-vozes da natureza à praça pública e, não obstante o fato de a sociedade, os legisladores e a opinião pública esperarem destes respostas simples, é forçoso constatar que os mesmos só poderão responder às perguntas formuladas em relação à ameaça do prião ${ }^{6}$, à possibilidade de um novo Chernobyl, aos impactos da contaminação por agrotóxicos e alimentos transgênicos, se levarem a público as suas dúvidas, se revelarem a insuficiência dos dados disponíveis, bem como as divergências existentes no interior da representada comunidade de pares.

Mais do que nunca, apresentar tais questões como dependendo unicamente da aplicação técnica é evitar um debate de objetivos múltiplos que deixaria a possibilidade de escolha na qual muitos pretendem fazer crer que exista um encadeamento necessário. Em relação às discussões envolvendo as agrobiotecnologias, por exemplo, nota-se um evidente esforço de um dos lados do debate em restringir a participação e a discussão pública. Os "agentes do otimismo tecnológico"7 , herdeiros do lluminismo, argumentam que apenas aos biólogos moleculares caberia o papel de decidir e opinar em relação à segurança dos organismos geneticamente modifi-

6 Proteína identificada como causadora do mal da vaca louca.

7 Tal denominação, assim como a de "críticos da cautela", tem sido empregada pelos autores a fim de nomear os agentes envolvidos nas disputas em torno das agrobiotecnologias no Brasil e, principalmente, no Rio Grande do Sul, de modo a poder caracterizar os distintos posicionamentos apreendidos da polêmica (Silveira, 2005; Silveira e Almeida, 2005a; Silveira e Almeida, 2000b). 
cados e, particularmente, das sementes de soja transgênica resistente ao herbicida Roundup. Defendendo a "teoria do determinismo genético", os mesmos sobrevalorizam o "fato científico" em detrimento de outros "valores sociais", e o resultado é que, ao simularem um debate democrático, o que pretendem é silenciá-lo em favor de uma sobrevalorização da biologia molecular em face das outras disciplinas científicas, ante a política e os interesses sociais. Alimentados por uma visão da inovação tecnocientífica enquanto "evolução" e "progresso" do conhecimento, em seu processo linear e cumulativo a propalam enquanto artifício dotado de um inquestionável potencial reparador, capaz de corrigir, per se, os impactos decorrentes do uso das tecnologias antecedentes ou, mesmo, de proporcionar soluções aos problemas sociais consagrados pelo mundo do senso comum.

No Entanto, lá onde os "agentes do otimismo tecnológico" vêem o "progresso", os "críticos da cautela" percebem os "impactos sociais e ambientais" da inovação tecnocientífica, representando-a dentro de um contexto de "imprevisibilidade" e "incontrolabilidade". Para esses, é como se os genes sempre tivessem a alternativa de se combinarem de algum modo fora do previsto e da normalidade do pensamento universal, como se o DNA não fosse um enigma desvendado de uma vez por todas, como se a natureza reagisse à sua artificialização naturalizando obras que fogem à nossa pretensão de controle. A teoria do gene fluido ${ }^{8}$ evoca justamente esta idéia de uma natureza contingente que evolui de forma concomitante à ação humana.

Tais posições, destacadas no Quadro 01 a seguir, acabam polarizando o debate público no Estado gaúcho e no Brasil e, a partir da instrumentalização de duas concepções distintas de natureza, irão propor também contrastantes

8 A idéia de gene fluido é defendida pelos "críticos da cautela" ao assumirem posições que se distinguem das engendradas pelos seus oponentes (idéia do determinismo genético). O gene fluido é então aquele que incorpora riscos, incertezas e ambigüidades, tornando-se arma de luta instrumentalizada na produção do contraponto. 
estratégias políticas de resolução da questão. De um lado, os que crêem em uma tecnosfera controlada pelos desígnios da razão humana justificam uma autonomia da tecnociência ante a política para apreender a objetividade do universo, mantendo, desta forma, a ruptura entre coletivos sociais e natureza, entre tecnociência e política. Do outro lado, estão aqueles que, percebendo as conseqüências impremeditadas (Giddens, 1991) engendradas pelos nossos artifícios tecnológicos, vêem como única possibilidade de resolução das controvérsias a construção de um debate tão amplo, tão informado e tão rigoroso quanto possível. Desde este ponto de vista, não se trataria, em absoluto, de considerar a opinião perita como possuindo o mesmo peso que outros valores e juízos sociais, muito menos de não privilegiá-la pelo seu magistério da objetividade, mas de levar à deliberação pública, além das suas certezas e hipóteses, as controvérsias e incertezas, reatando, assim, com os ensinamentos da Grécia antiga em relação à íntima interdependência entre ciência e democracia.

Quadro 1. "Agentes do otimismo tecnológico" e "críticos da cautela": representações da natureza, da inovação tecnológica e da ciência e suas projeções no debate público, a partir do contexto das lutas em torno das sementes de soja geneticamente modificadas no Estado do Rio Grande do Sul e no Brasil (Silveira, 2005; Silveira e Almeida, 2005a).

\begin{tabular}{|l|l|}
\hline \multicolumn{1}{|c|}{ Agentes do otimismo tecnológico } & \multicolumn{1}{|c|}{ Críticos da cautela } \\
\hline TECNOSFERA (natureza objeto) & TECNONATUREZA (natureza sujeito) \\
Progresso, avanço & Impactos sociais e ambientais \\
Determinismo genético & Gene fluido \\
Tenologia exata e conhecida & Tecnologia imprevisível e incontrolável \\
Liberação & Princípio da precaução \\
Fato científico & Valor social \\
Sobrevalorização da biologia molecular & Defesa da liberação entre iguais. Simetria \\
\hline
\end{tabular}


Assim, ora se tem o discurso que defende a liberação indiscriminada dos organismos geneticamente modificados no ambiente, tão propalado pelos "agentes do otimismo tecnológico", ora se constrói uma idéia de risco social que, herdando esta virtude grega do limite e da medida, presta atenção na singularidade dos casos e adota a precaução como regra de ação. Ao contrário da concepção de ciência monárquica, legitimada pela modernidade e de encontro ao autoritarismo do verdadeiro, que pretende silenciar a deliberação pública ao considerar como "medos irracionais", "emocionalismo", "terrorismo" e "obscurantismo" a visão crítica às inovações agrobiotecnológicas, percebe-se no discurso dos críticos um elogio à prudência.

Do ponto de vista ético, tal posicionamento crítico defende que "há uma obrigação de saber que passa por um reconhecimento da nossa ignorância: não possuímos o conhecimento científico dos efeitos futuros das nossas ações atuais" (Larrère e Larrère, p.272, 1997). Todavia, tal ponto de vista é também propositivo. Antes de incitar à inação perante os riscos associados à ação humana, os "críticos da cautela" defendem que uma ética intervenha junto à tecnociência: o princípio de precaução e uma série de normas e políticas criadas nos últimos decênios, para prevenir e administrar o lado sombrio da ação humana, podem assim encontrar aplicação no espaço político da democracia. Mas, mesmo que estes atores tenham em conta as incertezas do saber científico, não pretendem deste se separar. A razão dos críticos desloca o medo. Este último só pode ser concebido quando ainda se faz presente uma ética da ruptura, da separação entre tecnociência e política, natureza e coletivos sociais. Quando, a la Giddens, a razão, assim como a religião, é destradicionalizada, libertada do dogma, quando o processo de produção do conhecimento assume a sua base reflexiva, então as Luzes trocam de lugar. Já não se fala mais de uma tecnociência que dita os rumos da política, mas de uma ação deliberativa entre iguais orientada pelo conhecimento perito. Da Antigüidade retemos as práticas do bom uso e da prudência; da modernidade, a injunção do saber para agir. 
Mas então o que temos é um bom uso ecocentrado, fundado sobre um saber que deixou de ignorar os seus limites.

\section{Uma democracia para além do autoritarismo do cientifica- mente verdadeiro e do sociocentrismo?}

Quando o alemão Hans Jonas, em 1979, funda a "heurística do medo", isto é, quando defende que devemos investir num controle do artifício técnico que seja proporcional ao nosso poder de interferência na natureza, reconhece o lado sombrio da modernidade. No entanto, ainda mantém a separação entre sociedade e natureza. Ao denunciar a utopia técnica, conserva as ilusões do poder total. Ao procurar substituir a tecnociência pela ética (Jonas, 1994), mantém a sua separação. Creditando assim aos regimes autoritários a aptidão para lidar com os problemas ambientais, chega ao ponto de propor um modelo que, privilegiando o cenário do pior, acaba fazendo a apologia da inação. O medo, ainda associado ao "irracionalismo" e ao "emocionalismo", passa a orientar a crítica às idéias "evolucionistas" e "progressistas" da modernidade.

Contudo, usar o medo para influenciar os comportamentos não é muito eficaz. E eis, a título de ilustração, a imagem do fumante que, ameaçado de câncer, puxa de um cigarro para afastar o receio. Segundo Larrère e Larrère (1997), o que Jonas ignorou na sua "heurística" foi o domínio da racionalidade argumentativa, o modelo político da prudência, da deliberação, dentro do qual, o princípio da precaução busca o seu conteúdo e para o qual a idéia de que os homens são os principais autores dos males que os afetam marcam a nítida vontade de os remediar.

Tal é o modelo de construção social do risco. Isolá-lo, ver o que ele implica, como funciona, é apreciar-lhe as qualidades. Permite reunir duas competências, cada uma das quais deu as suas provas: a competência técnica 
para resolver as nossas relações com a natureza, a competência política para resolver os problemas humanos (Larrère e Larrère, p.234, 1997).

Assim sendo, trata-se de entregar a gestão biotecnológica a uma arbitragem política: ante as incertezas da razão (e não do irracionalismo) e, após um debate, o mais informado possível pela tecnociência, haverá que se resolver o irresolúvel, haverá que se responder às perguntas para as quais o atual estado da tecnociência só pode oferecer dúvidas, contradições e dissensos. Mas é preciso romper com esta visão dos "agentes do otimismo tecnológico", segundo a qual "basta entrever dúvidas sobre os OGMs para ser automaticamente identificado (...), como um guerreiro das forças do mal, alguém que impede cientistas de eliminar o maior fardo da humanidade, a fome" (Leite, p.1, 2004-a).

Se outrora a ciência pretendeu deslocar a tradição, em sua crescente ascensão das cosmogonias às cosmologias e, posteriormente, às positividades, o fato é que Ihe faltava, até há pouco, inscrever-se fora da tradição, negarse como dogma inquestionável. Os avanços do conhecimento proporcionados pela modernidade e os impactos da tecnonatureza permitem, finalmente, o questionamento dos fundamentalismos científicos (Giddens, 1991; Silveira e Almeida, 2005b; Silveira e Almeida, 2000a), a razão é chamada às claras, para explicar-se em um espaço deliberativo e democrático. Mas então, a responsabilidade social do cientista não é mais a de depositar, no espaço público, caixas-pretas contendo rótulos definitivos e fechados sobre temas, mas a de exercer contra ventos e marés o seu magistério da objetivação (Roqueplo, 1993 apud Larrère e Larrére, 1997). Magistério que apenas será válido se construído a partir de uma base reflexiva que, consagrando a perícia enquanto substituta inquestionável da tradição, inscreve no seu âmago o constante exame e reforma das práticas sociais "à luz de informação renovada sobre estas próprias práticas, alterando assim constitutivamente seu caráter" (Giddens, p. 45, 1996). 
Destradicionalização e inscrição da reflexividade na base do sistema, estes são desafios que, desde a instauração da modernidade até a sua radicalização atual, estiveram instigando a razão em seu vir-a-ser. Mas esses fenômenos desencadeadores da mudança institucional pela qual estaríamos passando também, conforme Giddens, seriam complementados pela sintomática globalização das práticas sociais, o que traria novas implicações ao habitus científico. E um exemplo pragmático e de grande relação com as recentes discussões envolvendo a biotecnologia e a biossegurança foi o precedente exercício de definição da biodiversidade enquanto "objetivo planetário". Segundo Larrère e Larrère (1997), o mesmo resultou de uma bem-sucedida articulação de um grande número de pesquisadores, espaIhados pelo mundo inteiro e representando diversas especialidades, sendo que o seu empenho repercutiu em uma aliança global em prol da defesa do patrimônio comum da humanidade, na Rio-92 e na sua Convenção da Biodiversidade, enfim, na confluência não apenas de interesses científicos, mas econômicos, políticos, sociais, morais, entre outros, em torno de uma questão de repercussão global. Exercendo o seu magistério da objetividade, os cientistas chamaram a atenção para os desafios da defesa da biodiversidade, levaram a público as suas dúvidas, hipóteses e controvérsias a respeito do tema (mudança climática, extinção de espécies, efeito estufa, etc.), a fim de que fossem desenhados cenários possíveis e a comunidade global se precavesse.

Mas, como diria Latour (apud Leite, 2004b), esta redefinição do papel do cientista não deixa de causar receios, e a prova disso são as representações de ciência e tecnologia instrumentalizadas pelos "agentes do otimismo tecnológico" em relação aos assuntos de biossegurança, as quais corroboram a competência dos biólogos moleculares, propondo que a Comissão Técnica Nacional de Biossegurança (CTNBio) fosse composta exclusivamente por estes últimos, em projeto sancionado em 2005 (Brasil, 2005). Eis uma sui generis repetição de Asilomar, mas que agora assume dimen- 
sões globais, visto que expandida aos países em desenvolvimento, antes deixados à parte os debates internacionais envolvendo a inovação tecnológica.

Vale lembrar, para tanto, que, em 1975, "logo após os cientistas terem demonstrado fortes preocupações com o anúncio do sucesso obtido na transferência de genes de uma espécie para a outra" (Kempf, p.49, 2004), foi organizada uma conferência pela Academia Americana de Ciências, em Asilomar, nome pelo qual a mesma ficou conhecida, sendo que o evento ocorreu praticamente a portas fechadas, reunindo uma elite de 140 pesquisadores que passaram quatro dias discutindo o futuro das pesquisas envolvendo as tecnologias de engenharia genética. O debate ficou centralizado nos aspectos de segurança das experiências sobre as regras que seriam necessárias para que as mesmas pudessem continuar sem que fosse ameaçada a liberdade dos cientistas. Como diria Kempf (p.48-49, 2004), de fato, os biólogos querem restringir ao mínimo a interferência do público ou do governo nos seus negócios (Kempf, p.48, 2004), sendo que, no final, a reunião alcança o objetivo da maioria dos biólogos moleculares: assegurar, sem interferência exterior, os procedimentos de controle e excluir o social da definição do problema (Ibidem, p.49).

Mas, segundo alguns, tal posição dos cientistas não mais se sustenta, uma vez que os mesmos estariam dando um "tiro no próprio pé" se pretendessem continuar defendendo o autoritarismo do cientificamente verdadeiro em questões tão controversas como é o caso dos assuntos envolvendo os aspectos de biossegurança das novas biotecnologias. O reconhecimento de competências distintas, e não apenas científicas, deve ser contemplado, o que resultou, no caso brasileiro, na criação do Conselho Nacional de Biossegurança (CNBS), ainda que a divisão de tarefas entre este e a CTNBio não esteja claramente definida, e que os biólogos moleculares mantenham "superpoderes" (Silveira, 2005; Silveira e Almeida, 2005a; Silveira e Almeida, 2005b) incompatíveis com a renovação institucional pretendida pelos avanços científicos e normativos precedentes, em torno dos 
princípios preservacionistas e democráticos (Princípio da Precaução, Convenção da Biodiversidade Biológica, Código de Defesa do Consumidor e Constituição Brasileira, Política Nacional do Meio Ambiente, entre outros).

Como diria Latour (apud Leite, 2004b), haja vista o fato de que "é preciso pensar sobre fluxo gênico, sobre leis, sobre isso e aquilo, sobre o número de elementos que vão entrar na reunião, que devem ser recrutados e aceitos sem serem simplificados", a discussão deveria cumprir, pelo menos, duas funções. A primeira seria considerar essa diversidade de interesses e entidades envolvidas. A segunda seria decidir como ordenar, ou compor, esses diferentes institutos, num mundo comum. Enfim, poderia fazer-se um paralelo com a construção de uma casa na qual há carpinteiros, encanadores, etc., que não estariam construindo várias casas diferentes, mas sim, trabalhando no mesmo prédio, no mesmo "cosmos" comum, para usar a velha expressão grega, o que, no caso dos organismos geneticamente modificados (OGMs), envolveria desde a política internacional, os subsídios, os aspectos legais, a ecologia da dispersão dos genes, onde encontrar experimentos que sejam públicos e convincentes, e assim por diante. Então, nesses termos, os biólogos moleculares, ao defenderem a tradição do autoritarismo do cientificamente verdadeiro, estariam errados, pois não estariam querendo que a sua tecnociência tenha sucesso.

Mas é preciso que haja realmente debate público e que as formas institucionais do saber não conduzam à imposição de um pensamento e de uma solução únicos, a favor de um governo, de um grande corpo de Estado ou de uma comunidade científica. E, neste sentido, não apenas a ditadura platônica ou, o que significa o mesmo, o autoritarismo do cientificamente verdadeiro, coloca uma ameaça real a este novo contrato institucional entre democracia e tecnociência, entre natureza e coletivos sociais. Se reconhecermos uma razão fundada na incerteza e na reflexividade, então já estaremos diante de uma "ciência mole" que não se incomoda em extravasar as suas contradições ao espaço público, mas ainda não teremos afastado o 
risco de os políticos sentirem-se cobrados a tomarem "decisões duras". A necessidade de estratégias e respostas definitivas por parte dos governos e Estados ante a política externa e interna nos coloca diante de um novo impasse que é o da chantagem do consenso. Ademais, neste processo de legitimação dos problemas ambientais e de biossegurança interferem estratégias econômicas, políticas e sociais, sem relação imediata com o objeto da preocupação. Corre-se, então, o risco de se esquecer de tratar a ameaça, para só se preocupar com os objetivos econômicos, políticos ou sociais (Larrère e Larrère, 1997).

\section{À guisa de conclusão}

Juntar tecnociência e democracia implica, portanto, dividir tarefas, não atribuir nem tanto à terra, nem tanto ao céu. A tecnociência já está preparada para pensar como uma montanha, segundo a Land Ethic (ecocentrada) de Aldo Leopold, um silvicultor que aprendeu e ensinou que, para respeitar e proteger a natureza, é preciso agir como se fôssemos este ser (terra) que queremos preservar em suas especificidades (Larrère e Larrère, 1997). Mas, então, a preservação implica em sair-se da polaridade "natureza objeto" e "natureza sujeito" (conforme apresentado no Quadro 01). A natureza é uma paisagem para cuja construção ou destruição participamos como co-produtores (ou co-destruidores) sem dispensar o exercício da razão. Mas não a razão do autoritarismo científico, defendida pelos "agentes do otimismo tecnológico" e instrumentalizada por interesses políticos - na chantagem do consenso - ou econômicos - na busca do lucro. Tentar agir como se fôssemos cada um dos elementos da natureza, tentar pensar como uma montanha implica não só a valorização da biodiversidade, mas também da sociodiversidade. E ninguém está mais apto para agir positivamente em relação à diversidade biológica do que os próprios nativos que, munidos com um olhar de partícipes, melhor conhecem o meio que pretendem preservar. 
Neste sentido, podemos afirmar que, "globalmente, o progresso é devastador: homogeniza, uniformiza, atenta contra a diversidade genética, contra a diversidade específica, contra a diversidade funcional, contra a heterogeneidade espacial, em suma, contra a biodiversidade" (Larrère e Larrère, p.323, 1997), da mesma forma que o saber que, ao se pretender universal, aniquila o que há de mais enriquecedor: o fortuito, o acaso, o imprevisto, a surpresa que nos causa o diferente, o diverso.

O pensar globalmente, agir localmente, está mais válido do que nunca. A tecnociência estendida em redes pelo mundo através dos sistemas peritos tem, neste novo contrato, a responsabilidade de auxiliar os coletivos sociais na construção da cidadania, a partir da validação dos saberes locais. Mas, se é possível pensar em alguma forma de universalização progressiva por extensão de experiências locais, reguladas por um objetivo comum negociado, isto é, se é possível pensar nesta lógica que é a da preservação de uma biodiversidade intimamente associada à diversidade cultural, então não podemos mais neglicenciar a questão dos poderes, da dominação, bem como o antigo debate democrático em torno das possibilidades das minorias, pois, nos termos de Touraine,

é preciso cessar de opor, retoricamente, o poder da maioria aos direitos das minorias. Não existe democracia se esses dois elementos não forem respeitados. A democracia é o regime em que a maioria reconhece os direitos das minorias porque aceita que a maioria de hoje venha a se tornar minoria no dia de amanhã e ficar submetida a uma lei que representará interesses diferentes dos seus, mas não lhe recusará o exercício de seus direitos fundamentais (p.29, 1996).

Só uma tecnociência que valide saberes e só um coletivo social que respeite as minorias estariam capacitados institucionalmente para lidar com um novo projeto de desenvolvimento que se pretenda durável, sustentável, bem como com as questões de biossegurança. Já não se trataria mais 
da importação de inovações dos países desenvolvidos, como é o caso dos OGMs, cujas patentes revertem para os Estados Unidos, mas que se difundem crescentemente pelo globo. Trata-se, sim, de deliberarmos quais os nossos reais problemas e desafios sociais, desenvolvermos tecnologias adequadas a eles e revertermos os seus benefícios a nosso favor. Enquanto as relações desiguais permitirem que os países megadiversos tenham seus recursos saqueados e patenteados pelos desenvolvidos, faltar-nos-á tudo, até capacidade para saber. Precisamos de uma tecnociência que produza taxonomistas que pretendam algo mais do que simplesmente servir aos interesses multinacionais de cobrança de royalties. Precisamos conhecer objetivamente a nossa diversidade, mas precisamos também, como précondição, valorizar a nossa sociodiversidade. Ambas andam de par.

Assim, muito embora o desenvolvimento durável e a biodiversidade sejam objetivos planetários, só podem realizar-se através de experiências locais, tirando partido dos recursos do território, das configurações sociais, das situações políticas e das possibilidades de aplicação, neste contexto, das tecnologias disponíveis. Se o cenário atual das discussões envolvendo as agrobiotecnologias e a questão da biossegurança no Brasil dão indícios, pelo fortalecimento da posição dos "agentes do otimismo tecnológico", de uma instrumentalização da tecnociência, através de uma legitimação do autoritarismo do cientificamente verdadeiro (refletida nos "superpoderes" da CTNBio), para encobrir interesses sociocêntricos que envolvem royalties, política internacional e relações de dependência, em uma busca pela manutenção do antropocentrismo moderno, esta posição, felizmente não é a única. Por trás das iniciativas difusas dos "críticos da cautela" podem-se vislumbrar muitos sinais de que a história da tensa relação entre tecnociência e democracia não mais se sustenta no silêncio. Se a monarquia lhe convinha, a incorporação das disposições democráticas e o avanço dos conhecimentos e dos problemas ambientais já começam a desenhar os contornos da sua mortalha. E uma nova ética, a partir desse estado dos fatos, 
inviabilizaria, definitivamente, o "salve-se quem puder". Todos vagueiam juntos no mesmo barco, em busca do norte: natureza e coletivos sociais, tecnociência e democracia.

\section{Referências}

BOURDIEU, P. Razões práticas: sobre a teoria da ação. Campinas: Papirus Editora, 1996.

BRASIL. Lei n. 11.105, de 24 de março de 2005. Disponível em: < http:// www.presidencia.gov.br/ccivil_03/_Ato2004-2006/2005/Lei/ L11105.htm>. Acesso em: 04 de maio de 2005.

GIDDENS, A. Introdução. As conseqüências da modernidade. São Paulo: Editora da Universidade Estadual Paulista, 1991.

GIDDENS, A. Duas teorias da democratização. In: GIDDENS, A. Para além da esquerda e da direita. São Paulo: Editora da Unesp, 1996.

JONAS, H. Técnica e responsabilidade: reflexões sobre as novas tarefas da ética. In: Ética, medicina e técnica. Lisboa: Vega Passagens, p.27-62, 1994.

KEMPF, H. Asilomar: a ciência aos cientistas. In: ZANONI, M. (org.). Transgênicos, terapia genética e células-tronco: questões para a ciência e para a sociedade. Brasília: Núcleo de Estudos Agrários e Desenvolvimento Rural, Instituto Interamericano de Cooperação para a Agricultura, 2004.

LATOUR, B. Jamais fomos modernos. Rio de Janeiro: Editora 34, 1994.

LATOUR, B. Políticas da natureza: como fazer ciência na democracia. Baurú: EDUSC, 2004.

LARRÈre, C.; LARRÈrE, R. Do bom uso da natureza. Para uma filosofia do meio ambiente. Lisboa: Instituto Piaget, 1997.

LEITE, M. Por que precisamos de um novo fórum para o debate público sobre biotecnologia. Science and Development Network - SciDev.Net, 2004. Disponível em: < http://www.scidev.net/ms/sci_comm/index.cfm? pageid=300 > . Acesso em: 21 de agosto de 2004a. 
LEITE, M. "Melhores verdades". Folha de São Paulo. São Paulo. Disponível em: $<$ http://www1.folha.uol.com.br/fsp/ciencia/fef209200401.htm >. Acesso em: 12 set. 2004.

SILVEIRA, C. A. da; ALMEIDA, J. Social Meanings of Biotechnologies. In: CONGRESSO BRASILEIRO DE ECONOMIA E SOCIOLOGIA RURAL, 48, Rio de Janeiro, 2000a.

SILVEIRA, C. A. da; ALMEIDA, J. Significados sociais das biotecnologias: o campo de disputas em torno das sementes transgênicas no Rio Grande do Sul. In: 24을 REUNIÃO ANUAL DA ANPOCS, Anais, Petrópolis, $2000 \mathrm{~b}$.

SILVEIRA, C. A. da. Significados sociais das biotecnologias: interesses e disputas em torno dos organismos geneticamente modificados (OGMs) no Rio Grande do Sul. 169 f. Dissertação de Mestrado (Mestrado em Desenvolvimento Rural) Programa de Pós-Graduação em Desenvolvimento Rural, Universidade Federal do Rio Grande do Sul, Porto Alegre, 2005.

SILVEIRA, C. A. da; ALMEIDA, J. Agentes sociais e disputas em torno das agrobiotecnologias: o caso da soja transgênica no Sul do Brasil. Cadernos de Ciência \& Tecnologia. Brasília: Embrapa, no prelo, 2005a.

SILVEIRA, C. A. da; ALMEIDA, J. Biossegurança e democracia: entre um espaço dialógico e novos fundamentalismos. Revista Sociedade e Estado. Brasília: v.20, n.1, p.73-102, 2005b.

TOURAINE, A. Uma idéia nova. In: TOURAINE, A. O que é democracia? Petrópolis: Vozes, 1996. 


\section{Resumo}

O crescente questionamento das idéias evolucionistas e das grandes narrativas que serviram de suporte, desde os clássicos, aos estudos nas áreas das ciências sociais tem desencadeado reações diversas no âmbito acadêmico. Se as tendências pós-modernas e as teses do fim da História se situam legitimamente neste espaço de possibilidades, não menos influentes são as propostas de releitura da realidade em que vivemos, a partir do projeto moderno e sua radicalização. É dentro deste último empreendimento que Anthony Giddens propõe a perspectiva de um novo pacto de segurança ontológica, que passa a ser construído em um mundo de sistemas abstratos que precisam ser reencaixados em dimensões globais. As discussões envolvendo as novas biotecnologias, em nível mundial e no Brasil, são reveladoras de características interessantes deste novo momento da humanidade. Os pontos de acesso desencadeados por pavores alimentares e preocupações ambientais fazem, neste sentido, mais do que diminuir a fidedignidade em relação ao conhecimento perito; provocam reordenamentos de implicações éticas, sociais e políticas bastante distintos da "heurística do medo", proposta pelo filósofo Hans Jonas. Como tais reordenamentos sinalizam para novas tendências no processo de gestão das tecnologias à luz da recente polêmica configurada em torno das novas biotecnologias no Brasil? É sobre esta questão que o presente texto pretende refletir.

Palavras-chave: Biotecnologias; Biossegurança; Construção social do risco; Ética ecocentrada; Democracia. 


\section{Technoscience, democracy, and ethical challenges of biotechnology in Brazil}

\section{Cristiane Amaro da Silveira and Jalcione Almeida}

The increasing questioning of the evolutionist ideas and the great narratives, the classics that served as support to the studies in the field of social sciences, has led to many different reactions within the academic context. Even though the postmodern trends and theories of the end of history have a right to be in this set of possibilities, no less influential are the proposals for revising the reality in which we live from the point of view of the modern project and its radicalization. It is within this project that Anthony Giddens proposes the prospect of a new ontological security pact, which will be built in a world of abstract systems that need to be reinserted in global dimensions. Discussions concerning new biotechnologies, both worldwide and in Brazil, reveal interesting characteristics of this new moment of human history. The access points that result from the fear of famine and environmental concerns, in this case, do more than reduce the reliability of the expert knowledge; they bring about the reorganization of ethical, social and political implications quite distinct from the "heuristic of fear" proposed by the philosopher Hans Jonas. How do such reorganizations point to new trends in the process of technology management in the light of the recent controversy surrounding the new biotechnologies in Brazil? This is the question that this article intends to discuss. Keywords: biotechnology, biosafety, social risk construction, environmental ethics, democracy 